\title{
MPs warn of threat to the science base
}

[LONDON] In its parting shot before the dissolution of the UK Parliament, the House of Commons Select Committee on Science and Technology warned that the pursuit by government departments of their individual agendas was threatening to undermine the strength of Britain's science base.

Two weeks ago, a similar warning was made in the context of the decision by the Ministry of Agriculture, Fisheries and Food (MAFF) to terminate funding for research at the Roslin Institute in Scotland that has led to the first successful cloning of an adult sheep (see Nature 386, 316; 1997).

The new warning comes in the committee's report on the activities of the Natural Environment Research Council, which was published last week. The report is based on a series of hearings over the past six months which concentrated in particular on NERC's involvement in research into climate change.

The committee was reluctant to endorse the criticism of several academic witnesses who complained at these hearings that NERC had shifted its research agenda too enthusiastically towards goals identified in the recent Technology Foresight exercise, to the detriment of research not lying within identified priority areas.

The committee agreed that the research community has "some grounds for its concern about NERC's commitment to basic research". But it accepted the research coun- cil's reassurance that the decline in responsive research is likely to be reversed, adding that, "from the evidence available to us at this stage, NERC's approach seems entirely reasonable".

The committee is less generous towards the government, however, claiming that individual departments are often led to take actions whose consequences - often unintended - shift an additional financial responsibility on to the research councils, and so effectively reduce the amount of science funding available for other activities.

One example cited by the committee is a decision by the Meteorological Office to reduce its funding for flights of a C-130 aircraft that had been converted to make atmospheric measurements, following the withdrawal of financial support from the Ministry of Defence.

John Krebs, the chief executive of NERC, admitted to the committee that he feared that new financial arrangements introduced by the Met Office to recover the costs of the C-130 flights made it possible "that the UK core capacity in atmospheric science will decline in the next five years". That is a fear that is widely shared among atmospheric scientists.

Another potential threat to NERC's budget highlighted by Krebs was the possibility that the research council might be asked to contribute directly to the support of the
European Space Agency's Earth Observation programme. At present, this support is being provided directly by the Department of Trade and Industry through the British National Space Centre.

"It is easy for each department to pursue the course which will increase its ability to concentrate upon functions it regards as its core, and maximize the resources it can devote to that core," says the select committee in its report. But it adds: "The government as a whole must be aware of the danger that even though the headline figure of the science budget may remain stable, a wider range of responsibilities will mean that it is spread more thinly and less effectively."

Parallel conclusions had been reached by a separate report on the research council system, published two weeks ago, which cited some harsh criticism heard in evidence from Ray Baker, secretary of the Biotechnology and Biological Sciences Research Council, of the poor level of scientific understanding of some government officials formally responsible for distributing research funds at MAFF.

The committee ended this report by urging its successor committee, which will be appointed after the general election on 1 May, to carry out an examination of the relationship between the science budget and the expenditure by individual departments on science and technology.

\section{US National Science Board seeks a wider role in policy-making}

[WASHINGTON] The US National Science Board (NSB) has endorsed an audacious plan to broaden its activities beyond the oversight of the National Science Foundation (NSF) and to offer broad science policy advice to both the administration and the Congress.

The board last week endorsed a plan to "expand its attention to larger national science and engineering policy issues". This would involve developing recommendations for how the government should set science priorities, and providing more analysis of the effectiveness of science policy in its biennial report, Science and Engineering Indicators.

The change has been instigated by Richard Zare, professor of chemistry at Stanford University and the new chairman of the science board (see Nature 382, 286; 1996). Zare promised that the board would address a "dysfunction" which, he said, was preventing the government from receiving clear advice from scientists on priorities.

"The science policy community seems to confront the question of setting priorities again and again without resolving it," he said.
The NSB was set up at the same time as the NSF, shortly after the Second World War, primarily to monitor the activities of the science agency, which funds most nonbiomedical university research in the United States. Some board members expressed misgivings about how deeply it should involve itself in the work of government agencies beyond its current role.

M. R. C. Greenwood, for example, chancellor of the University of California at Davis and a former senior official in the White House Office of Science and Technology Policy (OSTP), while voting for the plan, warned the board against talking about programmes in other agencies. She said that it "would stand a chance of losing its credibility" if it tried to participate in the government's annual budget process.

But Zare believes that it will be possible for the board to exercise wider influence as it is legally entitled to do, under its 1950 founding statute - by expanding on the existing data collection work that it does in preparing Science and Engineering Indicators. But he is also aware of the potential pitfalls. Last August, after chairing his first meeting of the board, Zare acknowledged that pursuing his new agenda would be "politically difficult and may cost the NSF support in the Congress".

Last week's meeting of the NSB also endorsed new procedures for the merit review of NSF grant proposals, along the lines suggested by a task force last year (see Nature 384, 399; 1996). The reforms will take effect in October, and will require referees to assess all proposals on the basis of their 'broader impacts' on, for example, education and society, as well as their intellectual merit.

In addition, the board announced the establishment of two major new supercomputing centres and the closure of two old ones. The new centres, which will operate as distributed facilities involving many partner institutions, will be based around the University of Illinois at UrbanaChampaign and at the University of California at San Diego.

The old centres, at Pittsburgh and at Cornell University, New York, will be phased out over the next two years. Colin Macilwain 